\title{
Sintering of Dental Porcelain Enamels
}

\author{
J. M. MEYER*, W. J. O'BRIEN, and C. U. YU \\ The University of Michigan, Ann Arbor, Michigan 48109, USA
}

This study showed the effects of sintering temperature and atmospheric pressure on the density, tensile strength, and microsiructure of porcelain enamels. Although the densities of the opaque porcelains were higher, they were weaker than the gingival porcelains. Gingival porcelains also glazed and sintered at lower temperatures than the opaque porcelains.

The densification of dental porcelain enamels involves sintering by viscous flow. Hodson ${ }^{1}$ studied the physical properties of dental porcelains. Vines and Semmelman ${ }^{2}$ studied the effect of air pressure on the densification of dental porcelain. Since these studies have been done, low fusing porcelains for use as enamels with metals have become widely used in dentistry. The purpose of this study was to determine the effects of firing temperature and pressure on the strength, density, and microstructure of selected porcelain enamels.

\section{Materials and Methods}

Disks of the porcelain were prepared by vibrating and condensing the porcelain powder mixed with water in a steel nold. The diameter of the mold cavity was $7.60 \mathrm{~mm}$ with a depth of $4.75 \mathrm{~mm}$. After the disks were dried, they were fired as follows. First, they were placed in a furnace for two minutes at $650 \mathrm{C}$. Next, the temperature was increased at a rate of $40 \mathrm{C}$ per minute to a final firing temperature. A total firing time of eight minutes was used for all specimens. Four samples of each porcelain were fired at five selected temperatures ranging from 760

This investigation was supported by General Research Grant RR -05321 from the National Institute of Dental Research, National Institutes of Health, Bethesda, Md.

Received for publication August 12, 1975.

Accepted for publication January 20, 1976.

- Permanent address: University of Geneva, Geneva, Switz.

a K. H. Huppert Co., Chicago, Ill. to 980 C. Ceramco air-fired gingival and opaque porcelains along with vacuum-fired gingival and opaque porcelains were tested. ${ }^{\mathrm{h}}$

After firing, the disks were bench cooled under a glass breaker. The density of each specimen was found by finding the weight change in water and applying Archimedes' principle. The tensile strength was determined by testing the disks in diametral compression. A cross-head speed of $0.05 \mathrm{~cm} / \mathrm{min}$ on the testing machine was used. After fracturing, the microstructure was studied using scanning electron microscopy. Both external and fractured surfaces were examined.

\section{Results}

DENsity.-The density of the porcelains fired at different temperatures is shown in Figure 1. Paired $t$ tests between densities at each temperature gave the following results. The vacuum-fired opaque porcelain samples were denser than the air-fired opaque porcelains at the 0.01 level of significance. The vacuum-fired gingival porcelains were denser than the air-fired gingival porcelains at the 0.001 level of significance. Finally, the airand vacuum-fired opaque porcelains were denser than the air- and vacuum-fired gingival porcelains at the 0.001 level of significance.

The differences in composition between the opaque and gingival porcelains $s^{3}$ is most likely the source of the differences in densities.

DiAmETRAL STRENGTH.-The mean strengths of the opaque air- and vacuum-fired porcelains at $982 \mathrm{C}$ were found to be $273 \mathrm{~kg} / \mathrm{cm}^{2}$ and $291 \mathrm{~kg} / \mathrm{cm}^{2}$, respectively. Those of the gingival air- and vacuum-fired porcelains were $452 \mathrm{~kg} / \mathrm{cm}^{2}$ and $408 \mathrm{~kg} / \mathrm{cm}^{2}$, respectively, at $955 \mathrm{C}$. Using $t$ tests, no significant differences $(P=0.05)$ were found between the

b Ceramco, Inc., Long Island City, NY. 
opaque air- and vacuum-fired strengths or between the gingival air- and vacuum-fired strengths. However, there was a significant

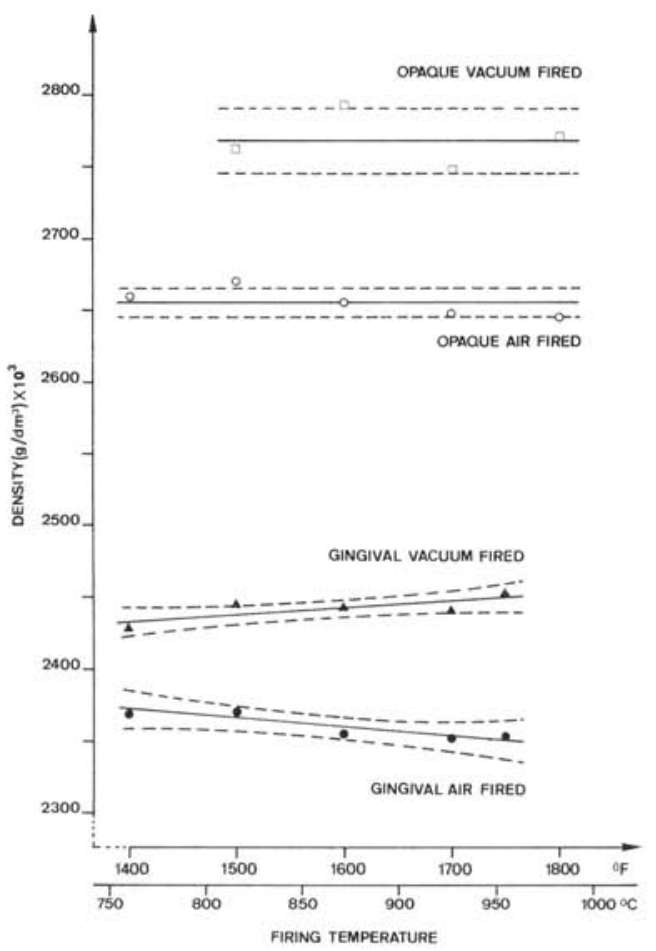

FIs 1.-Density of porcelains fired at different temperatures.

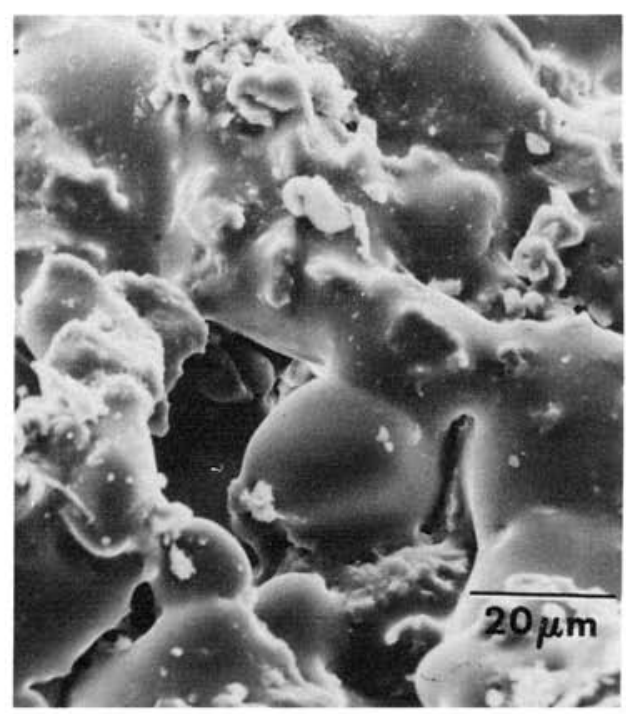

FiG 2.-Surface of air-fired gingival porcelain after firing at $760 \mathrm{C}(\times 1,000)$. difference $(P=0.02)$ between the strengths of the opaque and gingival porcelains. This may be attributed to the major differences in the composition ${ }^{3}$ of these two types of porcelain.

Microstructure.-The effect of firing temperature on the surface condition is shown in Figures 2 and 3 for the gingival porcelain and in Figures 4 and 5 for the opaque porcelain. It can be seen that the gingival porce-

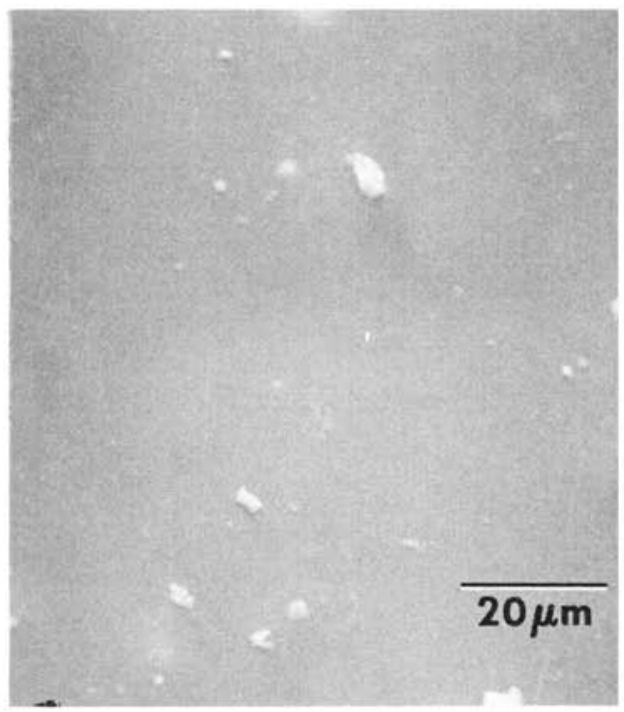

Fic 3.-Surface of gingival porcelain air fired at $955 \mathrm{C}(\times 1,000)$.

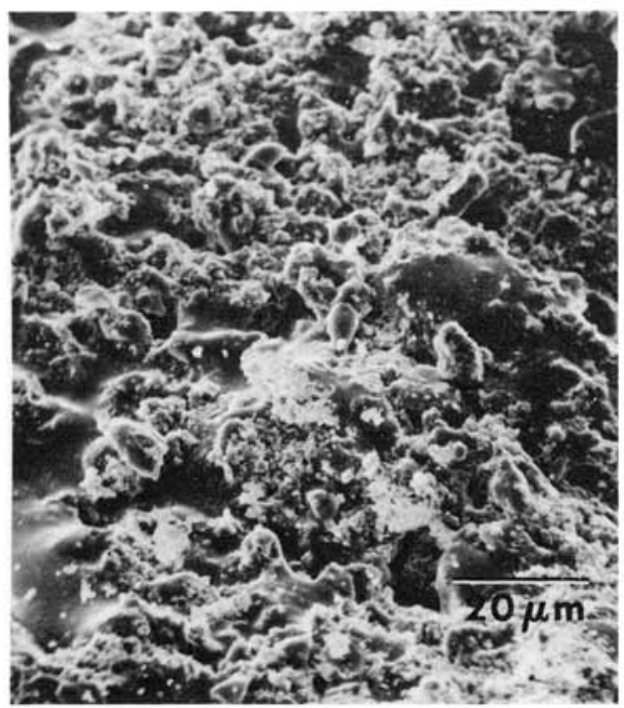

FIG 4.-Surface of opaque porcelain fired in vacuum at $760 \mathrm{C}(\times 1,000)$. 


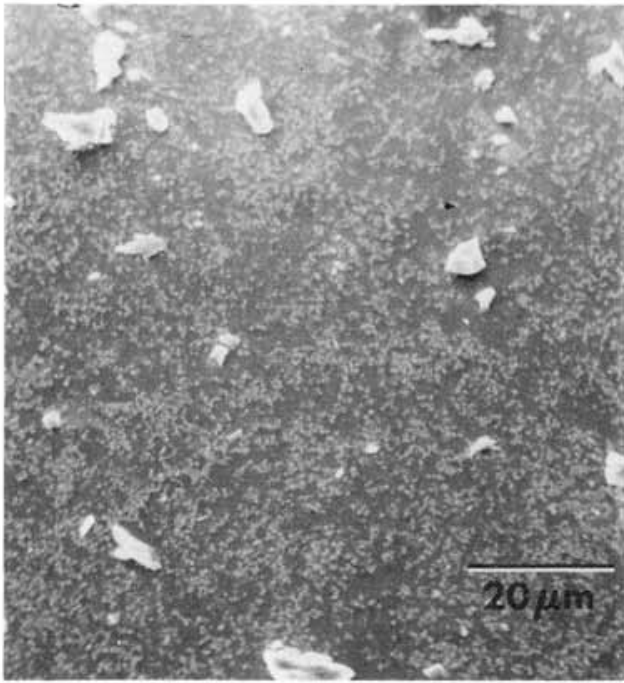

Fig 5.-Surface of opaque porcelain fired under vacuum at $1,010 \mathrm{C}(\times 1,000)$.

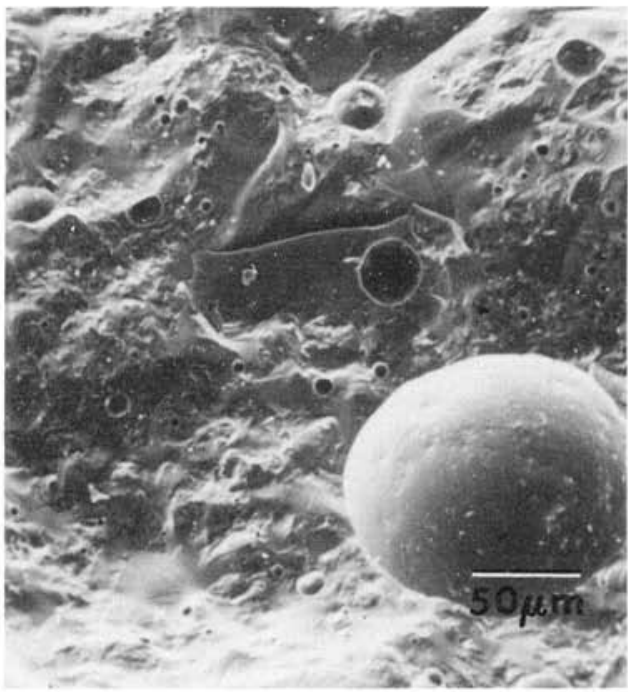

Fig 6.-Fracture surface of gingival porcelain fired at $815 \mathrm{C}$ in air $(\times 300)$.

lains glaze at a lower temperature than the opaque porcelains. The gingival porcelains were glazed at $955 \mathrm{C}$ whereas the opaque porcelains required $1,010 \mathrm{C}$ for glazing. This lower glazing temperature was observed for both gingival porcelains.

Vacuum-firing reduced the internal porosity of the gingival porcelains. Figures 6 and 7 show fracture surfaces of gingival

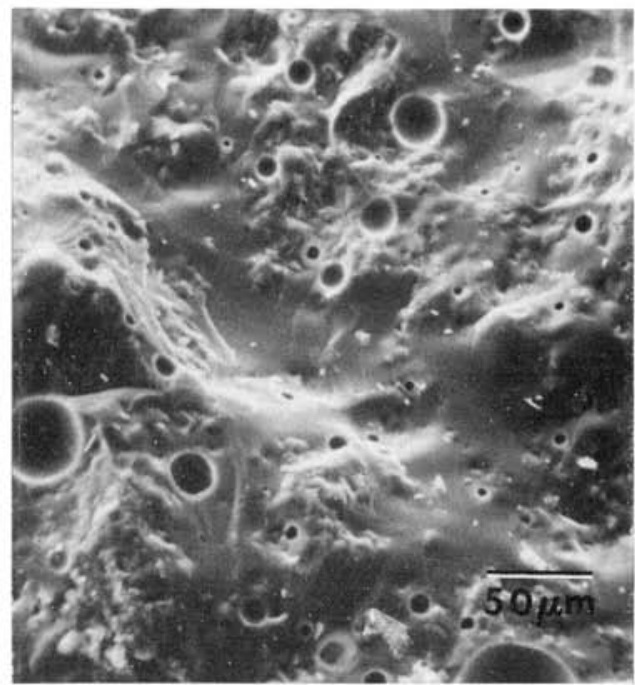

Fic 7.-Fracture surface of gingival porcelain fired at $955 \mathrm{C}$ in air $(\times 300)$.

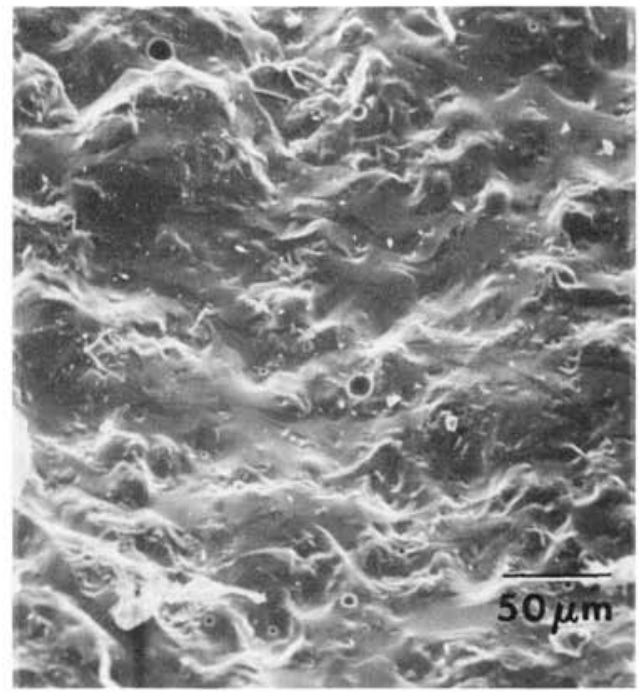

FIG 8.-Fracture surface of gingival porcelain fired at $955 \mathrm{C}$ under vacuum $(\times 300)$.

porcelain specimens fired in air. Many craters are seen that resulted from porosity. In contrast, the microstructure of vacuum-fired samples showed little porosity (Fig 8). Another finding was that the opaque porcelains showed considerable porosity even when vacuum fired (Fig 9). The lower strengths of the opaque porcelains are most likely due to a greater porosity and the presence of 


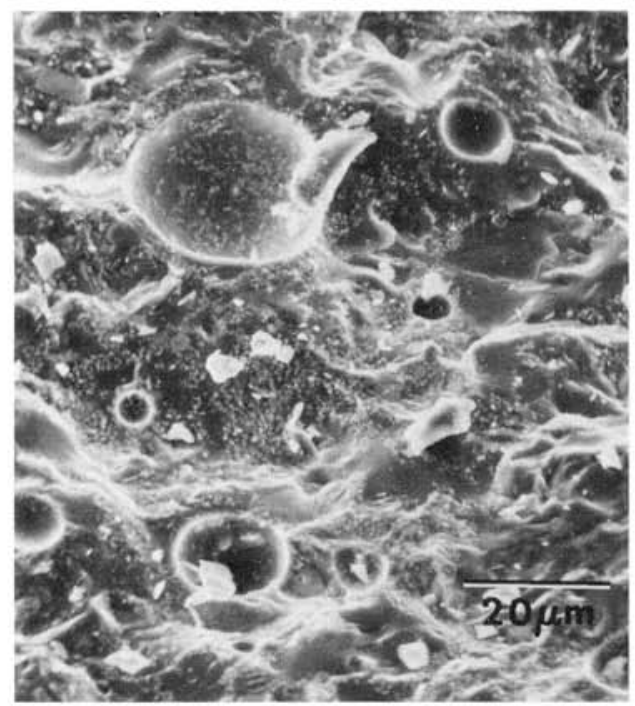

Fic 9.-Frácture surface of opaque porcelain fired under vacuum at $1010 \mathrm{C}(\times 1,000)$.

oxide opacifiers. Figure 10 shows a $\times 3,000$ magnification of the fracture surface of a vacuum-fired opaque porcelain. The opacifier is seen present as an agglomerated mass of smaller particles. Fracture striations are seen in the glassy matrix resulting from brittle failure.

\section{Conclusions}

The most significant findings of the study are that the gingival porcelains glaze at lower temperatures than the opaque porcelains; the opaque porcelains were weaker in strength than the gingival porcelains; vacuum-firing greatly reduced the porosity of

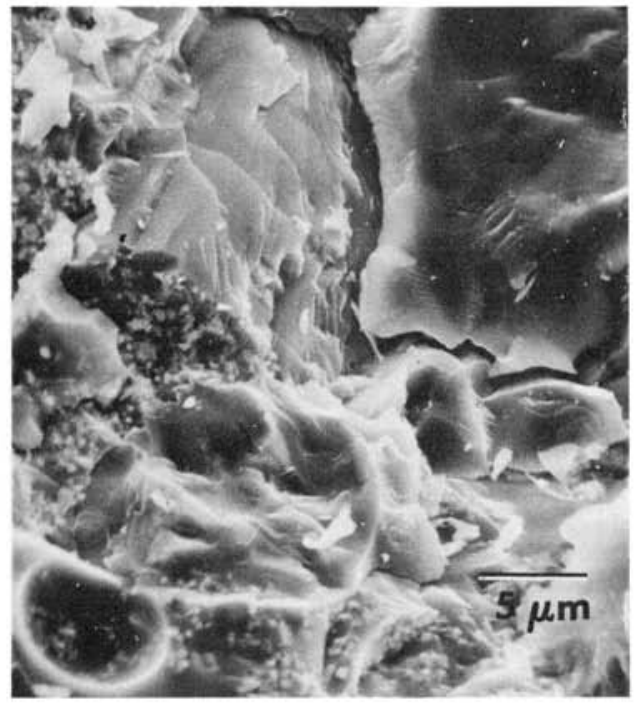

Fig 10.-Fracture surface of opaque porcelain fired in vacuum at $982 \mathrm{C}(\times 3,000)$.

the gingival porcelains but had little effect on the opaque porcelains; and the opaque porcelains had a higher density than the gingival porcelains.

\section{References}

1. Hodson, J.T.: Some Physical Properties of Three Dental Porcelains, J Prosthet Dent 9: $235,1959$.

2. Vines, R.F., and Sfmmelman, J.O.: Densification of Dental Porcelain, J Dent Res 36: $950,1957$.

3. Meyer, J.M.: Recherche Experimentale sur la Nature de la Liaison Ceramco-Metallique, PhD thesis, University of Geneva, Geneva, 1969. 